\title{
Yerel Halkın Turizmin Gelişimine Yönelik Algı ve Desteğinde Yer Kimliği ve Yer İmajının Rolü*
}

\section{The Role of Place Identity and Place Image in the Perception and Support of Residents towards Tourism Development}

\author{
Hülya Yeşilyurt, ${ }^{\mathrm{a} * *}$ Nilüfer Koçak ${ }^{\mathrm{b}}$ \\ a Araş. Gör.Dr., Adıyaman Üniversitesi, Turizm Fakültesi, Turizm İşletmeciliği Bölümü, Adıyaman/Türkiye. \\ ORCID: 0000-0002-9991-2557
}

bProf.Dr., Dokuz Eylül Üniversitesi, İzmir Meslek Yüksekokulu, İktisadi ve İdari Programlar, İzmir/Türkiye. ORCID: 0000-0002-9299-4553

\section{MAKALE BILGİSI}

Makale Geçmişi:

Başvuru tarihi: 01 Ekim 2019

Düzeltme tarihi: 06 Mart 2020

Kabul tarihi: 23 Mart 2020

\section{Anahtar Kelimeler:}

Yerel Halk

Turizm Gelişimi

Alg1

Destek

Yer Kimliği

Yer İmaj1

\section{ARTICLE INFO}

\section{Article history:}

Received 01 October 2020

Received in revised form 06 March 2020

Accepted 23 March 2020

Keywords:
Resident
Tourism Development
Perception
Support
Place Identity
Place Image

ÖZ

Bu çalışmanın amacı, Adıyaman il merkezinde yaşayan yerel halkın turizm gelişimine yönelik algı ve desteğinde yer kimliği ve yer imajının rolünü ortaya koymaktır. Bu amaç doğrultusunda ilgili alanyazın çerçevesinde bir model geliştirilmiştir. Çalışmada veriler, anket tekniği yardımı ile elde edilmiş ve geçerli 698 veri üzerinden analizler yapılmıştır. Analiz sonucunda yer kimliğinin yerel halkın turizmin olumlu etkilerine yönelik algılarını, yer imajının da turizmin olumsuz etkilerine yönelik algılarını etkilediği saptanmıştır. Yerel halkın yer kimliği ve yer imajı algılarının turizme yönelik desteğini doğrudan etkilemediği görülmüştür. Yerel halkın turizm gelişimine yönelik desteği de turizmin algılanan olumlu ve olumsuz etkileri ile açıklanmaktadır. Elde edilen bulgular doğrultusunda ilgili alanyazına ve sektöre yönelik öneriler geliştirilmiştir.

\section{Giriş}

Yerel halkın turizmin gelişimine yönelik desteği, turizmin etkilerinin yerel halk tarafından nasıl algılandığına bağlı

\begin{abstract}
A B S T R A C T
Aim of the study is to reveal the role of place identity and place image in the perception and support of the residenst living in the city center of Adiyaman towards tourism development. In accordance with this purpose, a model has been developed within the framework of the related literature. Data were obtained with the help of the survey technique and analyzes were performed through the 698 valid data. As a result of the analysis, it was found that the identity of the place predicted the residents' perceptions about the positive effects of tourism and the place image predicted the perceptions of the negative effects of tourism. It has been observed that residensts' perception of place identity and place image does not directly affect their support for tourism. The support of resident for tourism development is explained by the perceived positive and negative effects of tourism. In accordance with the findings obtained, suggestions have been developed for the related literature and sector.
\end{abstract}

*Bu çalışma, 2019 yılında Prof.Dr. Nilüfer Koçak danışmanlığında Dokuz Eylül Üniversitesi, Sosyal Bilimler Enstitüsünde tamamlanan "Yerel Halkın Turizmin Gelişimine Yönelik Desteğinde Yer Kimliği ve Yer İmajının Rolü: Adıyaman Örneği” adlı doktora tez çalışmasından türetilmiştir.

**Sorumlu yazar/Corresponding author

e-posta: hyesilyurt@adiyaman.edu.tr

e-ISSN: 2149-4622. (C) 2013-2020 Muş Alparslan Üniversitesi. TÜBİTAK ULAKBİM DergiPark ev sahipliğinde. Her hakk1 saklıdır. http://dx.doi.org/10.18506/anemon.628054 
sebeplerden ötürü yerel halkın ilgisi ve desteği olmadan yürütülen turizm faaliyetlerinin başarılı olması beklenmemektedir (Yoon ve diğerleri, 2001). Bu doğrultuda yerel halkın turizme yönelik algılarını anlamak ve etkili faktörleri belirlemek, turizme yönelik olumsuz algıları azaltmada ve olumlu algıları da en üst düzeye çıkarmada yardımcı olmaktadır (Almeida-García ve diğerleri, 2016; Stylidis ve diğerleri, 2014).

Uluslararası ve ulusal alanyazında yerel halkın turizmin gelişimine yönelik desteği genellikle Sosyal Değişim Teorisi (SDT) ile incelenmektedir. SDT'sine göre yerel halkın turizm gelişimine yönelik desteği, yerel halkın turizmin etkilerine yönelik algısı ile ilgilidir. $\mathrm{Bu}$ teori yaygın olarak kullanılsa da yerel halkın algılarını açıklama konusunda yetersiz olduğu belirtilmektedir (Hadinejad ve diğerleri, 2019). Nitekim konuyu açıklamada yeni teorilere ve yaklaşımlara ihtiyaç duyulmakta ve bu yönde çalışmalar yapılmaktadır (Hadinejad ve diğerleri, 2019; Yeşilyurt ve Koçak, 2018). Bu durumda yerel halkın turizme yönelik desteğini kolaylaştıran veya engelleyen değişkenler hakkında daha fazla araştırma yapılmasının gerekliliği ortaya çıkmaktadır.

Yerel halkın turizme yönelik alg1 ve desteği durağan değildir ve zamanla değişebilir. Yerel halkın turizm gelişimine yönelik algı ve desteğinde bir genelleme yapılamamasının nedenleri olarak yerel halkın alg1 ve tutumlarının araştırma yapılan bölgeye, bölgedeki turizm çeşidine ve turistik bölgenin gelişim düzeyine göre farklılaşması gösterilebilir (Faulkner ve Tideswell, 1997; Oviedo- García ve diğerleri, 2008: 97). Turizmin algılanan etkileri, toplumdan topluma değişebilmektedir. Bununla birlikte turizmin başarılı bir şekilde sürdürülebilmesinde etkisi oldukça fazla olmasından dolayı birçok araştırmacı yerel halkın turizmin gelişimine yönelik alg1 ve desteğini araştırma konusu yapmıştır (Stylidis ve diğerleri, 2014). Yapılan çalışmalarda yerel halkın turizmin algılanan etkisi ile turizm gelişimine yönelik desteği arasında doğrudan ilişkiler incelenmekle birlikte dişsal değişkenler ile turizmin algılanan etkileri ve turizme yönelik destek arasında hem doğrudan hem de dolaylı ilişkiler de incelenmektedir (Gursoy ve diğerleri, 2019). Bu çerçevede toplumsal bağlılık (McCool ve Martin, 1994; Lee, 2013), yaşam tatmini (Arslan Ayazlar ve Ayazlar, 2016; Uysal ve diğerleri, 2016), toplumsal güçlendirme (Boley ve diğerleri, 2014), yer aidiyeti (Dedeoğlu ve diğerleri, 2018), yer kimliği (Wang ve Xu, 2015; Wang ve Chen, 2015), yere bağlılık (Strzelecka ve diğerleri, 2017), yer imajı (Ayazlar, 2016; Stylidis ve diğerleri, 2015; Stylidis ve diğerleri, 2016), duygusal bütünleşme (Woosnam, 2011; Woosnam, 2012), sosyal kimlik (Ayazlar ve diğerleri, 2015; HaobinYe ve diğerleri, 2014) gibi farklı değişkenler ile yerel halkın turizme yönelik alg1 ve desteği arasındaki ilişki ile ilgili araştırmalar yapılmıştır. Araştırmalarda yerel halkın turizm gelişimine yönelik desteğinin sadece turizmin etkilerine yönelik algıları ile açıklanamayacağı; bu destekte farklı değişkenlerin de etkili olabileceği görülmüştür.

Adıyaman, kültür turizmi açısından Türkiye'nin önemli turistik bölgelerinden biri olmasının yanı sıra içinde bulunduğu coğrafi konum sayesinde inanç turizmi, gastronomi turizmi ve doğa turizmi gibi turizm çeşitleri açısından da oldukça önemli bir potansiyele sahiptir. Adıyaman'a gelen turist sayısına ait istatistikler incelendiğinde önemli bir turist yoğunluğunun olmadığı görülmektedir. Bölgede turist yoğunluğunun olmamasında ülkede yaşanan olumsuzlukların yanı sıra illerin gelişmişlik siralamasına göre Adıyaman ilinin 66. Sirada yer alarak, çevre iller olan Malatya, Gaziantep ve Şanlıurfa illerine göre geride kalması (Acar ve diğerleri, 2019:35), tanıtım eksikliği ve komşu illerin turizmde ön plana çıkması gibi pek çok faktörün etkili olduğu düşünülmektedir. Yerel halkın turizm konusunda bilinç eksikliği ve turizme bakış açısı da sektörel gelişme önünde toplumsal bir bariyer oluşturmaktadır (Yılmaz ve Çalışkan, 2015). Açıkçası, yerel halkın görüşlerinin önemsenmediği ve turizme katılımının olmadığı bölgelerde turizm gelişiminin uzun vadeli bir başarı elde etmesi mümkün olmamaktadır (Yoon ve diğerleri, 2001). Turizm gelişim politikalarının başarısı ve sürdürülebilirliği için paydaş iş birliği ve paydaş katılımı önemli görülmektedir.

Alanyazında turistik açıdan gelişmiş bölgelerin yanı sıra turistik açıdan gelişmekte olan bölgelerde ikamet eden yerel halkın turizme yönelik algı ve tutumlarına yönelik çok sayıda araştırma yapıldığı görülmektedir (Oğuzbalaban, 2017). Buna karşın Adıyaman'da yaşayan yerel halkı konu edinen herhangi bir çalışmaya rastlanılmamıştır. Bu nedenle araştırmada, yerel halkın yer kimliği ve yer imajı algıları ile turizm gelişimine yönelik alg1 ve desteği arasındaki ilişki incelenmiştir.

\section{Kavramsal İnceleme}

Turizmin yer temelli bir olgu olması, turizm gelişiminin bölgenin fiziksel özelliklerinden bağımsız bir şekilde gelişememesine sebep olmaktadır. Nitekim turizm deneyiminin büyük kısmı, zaman içinde değişen talep ve arz faktörleri arasındaki etkileşimin bir sonucu olarak fiziksel ortamlarda ortaya çıkmaktadır. İnsanlar, turistik bölgelerde boş zaman etkinliklerine katılmak ve tatil deneyimleri yaşamak amacıyla seyahat etmektedirler (Uysal ve diğerleri, 2012). Turistlerin yere yönelik algıları, tatil bölgesi seçimini ve tavsiye etme ve tekrar ziyaret etme gibi davranışsal niyetlerini etkilemektedir (Stylidis ve diğerleri, 2017). Öyle ki, turistik bölge planlamalarında turistlerin yere yönelik algıları önemli görülmektedir. Ancak turistik bölgelerin sadece turistlerin beklentilerine göre planlanması, uzun vadede turizmin gelişimini olumsuz etkileyebilir. İnsanların yaşadıkları yerlere karşı hissettikleri duyguların incelenmesi ve bu duygular göz önünde tutularak hareket edilmesi, yere yönelik algılarını ve tutumlarını etkileyebilmektedir (Hidalgo ve Hernández, 2001). Bu bakımdan yerel halkın yere yönelik algıları, turizmin amaca uygun bir şekilde planlanması açısından önemlidir. Yerel halkın turizme yönelik alg1 ve desteği araştırılırken bir yerin hem duygusal hem de fiziksel değerlendirmelerinin de dikkate alınması gereklidir. $\mathrm{Bu}$ kapsamda yer kimliği ve yer imajı yerel halkın turizm gelişimine yönelik desteğini açıklamada yeni değişkenler olarak kullanılmaktadır.

\subsection{Yer Kimliği}

İnsanların yaşadıkları yer ile etkileşimleri ve deneyimleri sonucunda aralarında güçlü bir bağ oluşmaktadır (Tuan, 1977). Yere olan ilginin, tutumlara, değerlere ve inançlara bağlı olmasından dolayı zaman içerisinde insanlar ve yer arasındaki bu bağ gelişir ve güçlenir (Stylos ve diğerleri, 2017: 18). Alanyazında insanların yaşadıkları yer ile aralarındaki ilişkinin ve bağın anlaşılmasında yer duyusu 
(sense of place), yere bağlilık (place attachment) ve yer kimliği (place identity) gibi kavramlar kullanılmaktadır (Göregenli, 2013:174; Lewicka, 2010:32). İnsanların içinde yaşadıkları yer ile aralarında kurdukları ilişkiye dayalı olarak oluşan duygusal bağ, yere bağlılık olarak tanımlanmaktadır (Herna'ndez ve diğerleri, 2007:310; Shumaker ve Taylor, 1983). Yer kimliği ise yaşadıkları yere yönelik bağlılıklarının gelişiminde, yere yönelik geliştirdikleri anlamların kimliklerinin bir parçası haline gelmesidir (Göregenli ve diğerleri, 2014: 75). İnsanlar bir yere duygusal olarak bağlandıklarında, bir yerle özdeşleştiklerinde veya kendilerini o yere ait hissettiklerinde yer kimliği duygusu geliştirirler (Tsai, 2016: 539).

Yer kimliği, bir yerin diğer yerlerden ayırt edilebilmesini sağlayan niteliklerinin bir araya gelmesi ile oluşmaktadır. $\mathrm{Bu}$ özellikler o yerde yaşayan insanlar tarafindan farklı algılanmasını ve insanların o yere bir değer yüklemesini sağlamaktadır. İnsanlar yer kimliğini ikamet ettikleri ev, mahalle, şehir ya da dinlenme ve eğlenme amaciyla gittikleri doğa, orman gibi doğal veya yapılandırılmış çevreye yönelik geliştirebilirler (Lewicka, 2010). Özellikle de kültürel miras özelliğine sahip yerler insanlarda farklı duygular ve anlamlar yaratabilir (Rasoolimanesh ve diğerleri, 2017a). Nitekim bir yerin sahip olduğu parklar, eğlence olanakları, doğal güzellikler, tarihi ve kültürel değerleri o yere özgü bir kimlik kazandırmaktadır. Örneğin Las Vegas-Kumarhaneleri, Kanada-Niagara Şelalesi, Orlando-Disneyland, Paris-Eyfel, Misır-Piramitler, İzmirEfes Antik Kent, Nevşehir-Peribacaları, DenizliPamukkale, Adıyaman-Nemrut ile özdeşleşmiştir. Bir kişinin kimliği ile yaşadığı yerin kimliği arasında bir ilişki olabilir. $\mathrm{Bu}$ nedenle, bir kişinin yer kimliği algısının yaşadığı yere verdiği duygusal ve sembolik değerleri içerdiği söylenebilir (Argan ve diğerleri, 2015: 4).

Kimlik bir kişinin davranışını belirleyen önemli faktörlerden biridir. Son yıllarda yapılan çalışmalarda, yerel halkın turizme yönelik destekleyici tutumunu anlamada yer kimliğinin önemi vurgulanmaktadır ( $\mathrm{Gu}$ ve Ryan, 2008; Nunkoo ve Gursoy, 2012; Wang ve Xu, 2015). Wang ve Chen (2015) yerel halkın turizme yönelik davranışlarının değerlendirilmesinde turizmin etkilerine yönelik algıların yanı sıra yerel halkın yer temelli kimlik algısının da göz önünde bulundurulması gerekliliğini öne sürmektedir. Nitekim turizm yönelik destek sadece SDT açısından değil, aynı zamanda kişisel değer sistemleri ve yer kimliği açısından da açıklanmalıdır (Chen ve diğerleri, 2017: 341; Wang ve $\mathrm{Xu}, 2015: 248)$. Yer kimliği teorisi de, yerel halkın turizm gelişimine yönelik algı ve desteğinin, yerel halkın yaşadığı yeri kendi kimliği ile özdeşleştirmesi ile açıklanabileceğini öne sürmektedir (Gu ve Ryan, 2008; Wang ve Chen, 2015). Teoriye göre yer kimliği algıs1 yüksek olan yerel halk, bölgenin turistik açıdan gelişmesini istemektedir. Turizmin gelişmesi ile birlikte bölgenin ekonomik olarak gelişmesi beklendiği için turizmin olumsuz etkileri göz ardı edilebilecektir (Gursoy ve Rutherford, 2004). Özellikle de bir yerin ayırt edici özellikleri, yerel halkın yaşadıkları yeri turistik bir bölge olarak görmelerini sağlamakta ve dolayısı ile turizme yönelik yapılan plan ve politikalara katılımlarını sağlamaktadır (Stylidis ve diğerleri, 2014).

\subsection{Yer İmaj1}

İmaj ile ilgili yapılan çalışmalarda genel olarak imajın, tüketici davranışlarına olan etkisi araştırılmaktadır (Jenkins, 1991: 4). İmaj; insanların bir nesneye, bir ürüne ve bir yere yönelik olarak izlenimleri, inançları ve fikirleri olarak tanımlanmaktadır (Kotler, 2000: 553). Paralel olarak yer imajı da insanların yaşadıkları yer ile ilgili izlenimleri veya algılamalarıdır. Turistlerin ziyaret ettikleri yerin imajı ile ilgili değerlendirmeleri davranışsal niyetleri etkilediği gibi yerel halk da bu imajdan etkilenmektedir. Yer imajı algıları olumlu ise yerel halk yaşadıkları yeri yaşanabilir ve çalışılabilir bir yer olarak görebilir, olumsuz ise bu yeri kendi evi gibi sahiplenmeyebilir (Dean ve diğerleri, 2019: 2). Olumlu yer imajına sahip yerel halkın, yaşadıkları yeri turistik bir destinasyon olarak görmekte ve başkalarına tavsiye etme davranışını göstermeleri beklenmektedir (Schroder, 1996; Stylidis ve diğerleri, 2015). Bu açıdan bakıldığında yerel halkın yaşadıkları bölge için gönüllü bir turizm elçisi olduğu söylenebilir. Yer imaj1 turistlerin ziyaret ettiklerin yerin deneyiminde etkili olduğu kadar yerel halkın yer imajı da yaşadıkları yer ile ilgili memnuniyetinin belirleyicisidir. Bu bağlamda bir şehirde yaşayan insanların, o yerin toplumsal hizmetler, sosyal çevre, fiziksel ve sosyal olanaklar gibi özelliklerine yönelik algıları oldukça önemlidir.

Bir yerde turizmin gelişmesi için öncelikle yerel halkın yaşam standartlarının yükseltilmesi gereklidir (Türker ve diğerleri, 2016: 3). Bölgede bulunan halkın yaşam standartlarının artmasında yer imajı önemli bir faktördür. Yer imajına ilişkin alt ve üst yapı imkanları, sosyal çevre, tarihi doku ve doğal çevre gibi faktörlerin, bölgede yaşayan yerel halkın yaşam kalitelerini olumlu etkilemesi muhtemeldir (Sevim ve diğerleri, 2013: 126).

Çevre psikolojisi alanyazınında, yerel halkın yer imajı algılarının şehir planlaması ve gelişimi projelerini etkilediği vurgulanmaktadır. $\mathrm{Bu}$ doğrultuda yerel halkın yer imajı algıları, yaşadıkları yer için yapılacak planların etkinliği, başarısı ve sürdürülebilirliği açısından önemlidir (Stylidis, 2016). Paydaş teorisine göre turizm politikalarının ve planlamaların hazırlanmasında yerel halk ile iş birliği yapılması ve yerel halkın katılımının sağlanması önemlidir (Stylidis ve diğerleri, 2016). Turizm gelişiminde rol oynayan paydaşlar; turistler, yerel halk, girişimciler, yerel yönetimler ve sivil toplum kuruluşları olarak bilinmektedir (Goeldner ve Ritchie, 2002: 414; Garcia ve diğerleri, 2012:650). Yerel halkın olumlu yer imaj algısının, yerel halkın turizm plan ve politikalarına yönelik davranışlarını etkileyeceği düşünülmektedir (Stylidis, 2018). Turizme yönelik planlamalar yapılırken turistlerin yanı sıra yerel halkın da yer imajı algılarının araştırılması gerekmektedir (Stylidis ve diğerleri, 2014).

\section{Yöntem}

\subsection{Araştırmanın Evreni ve Örneklemi}

Araştırma evrenini, Adıyaman il merkezinde ikamet eden 18 yaş ve üstü olan yerel halk oluşturmaktadır. 2017 yılı Adıyaman il merkezinde ikamet eden 18 yaş üstü kişi sayısı kişi sayısı 162,956'dır (Adıyaman Valiliği, 2017). Zaman ve bütçenin az olması, evrenin büyüklüğü ve ulaşılması gereken katılımcıların coğrafi olarak geniş bir bölgede olması gibi nedenlerden dolayı evrenin tamamına ulaşılamadığından örneklem grubu belirlenmiştir. Evrenin tamamıma ulaşılması mümkün olmadığı durumlarda veya 
100 milyonun üzerinde evren büyüklüğü olduğunda 0,05 örnekleme hatası ile örneklem sayısının 384 olmasının yeterli olabileceği belirtilmektedir (Ural ve Kılıç,2011: 49; Yazıcıoğlu ve Erdoğan, 2011: 88-89). Dolayısıyla en az 384 katılımc1 sayısı yeterli olacağı düşünülmüss ve AğustosEkim 2018 tarihleri arasında tesadüfî olmayan örnekleme yöntemlerinden kolayda örnekleme yöntemi ile geçerli 698 kişiden kullanılabilir veri toplanmıştır. Toplanan veri sayısının evreni temsil etmede yeterli olduğu söylenebilir.

\subsection{Veri Toplama Aracı ve Teknikleri}

Araştırmada veriler, anket tekniği ile elde edilmiştir. Anket iki bölümden oluşmaktadır. Birinci bölümde değişkenlere yönelik ifadeler, ikinci bölümde katılımcıların sosyodemografik özelliklerini belirlemeye yönelik ifadeler bulunmaktadır. Turizm gelişimine yönelik algı (TGYA), turizm gelişimine yönelik destek (TGYD), yer kimliği ve yer imajı değişkenlerine yönelik ifadeler 5'li likert ölçeğine göre düzenlenmiştir. Yerel halkın yer kimliği algılarının ölçülebilmesi amacıyla Wang ve Xu (2015) tarafindan geliştirilen ölçek kullanılmıştır. Geçerliliği ve güvenirliği Wang ve Chen (2015), Wang (2016) çalışmalarından sağlanan ölçek ayırt edicilik, süreklilik, özsaygı ve öz yeterlilik olmak üzere 4 alt boyuttan ve 12 ifadeden oluşmaktadır. Ölçek, araştırmacı tarafından Türkçe'ye çevrilmiş; iki araştırmacı ile İngiliz Dili ve Edebiyatı alanında lisans ve yüksek lisans eğitimi almış bir okutman tarafından anlaşılırlığı kontrol edilmiştir.

Yerel halkın yer imajı algılarını ölçmek amacıyla Stylidis ve diğerleri (2014) ile Stylidis'in (2016) çalışmalarında kullanılan ölçek kullanılmıştır. Ölçek fiziksel görünüm, sosyal çevre, sosyal olanaklar ve toplumsal olanaklar olmak üzere dört boyut ve 14 ifadeden oluşmaktadır. Ölçek, Ayazlar (2016) tarafindan yapılan araştırmadan yararlanılarak Türkçe'ye uyarlanmıştır.

Yerel halkın turizm gelişimine yönelik algısını belirlemek amaciyla Gursoy ve Rutherford (2004)'un ilgili alanyazından yararlanarak hazırlamış olduğu ölçek kullanılmıştır. Ölçek, ulusal alanyazında yer alan çalışmalardan yararlanılarak Türkçe'ye çevrilmiştir. Aynı ölçek Nunko ve Gursoy (2012) tarafindan kullanılmış olup, turizmin algılanan olumlu ve olumsuz etkileri şeklinde iki faktöre ayrıldığı görülmüştür. Alanyazında yerel halkın turizme yönelik algılarını, olumlu ve olumsuz olarak iki ayrı boyutta inceleyen birçok çalışma bulunmaktadır (Wang ve Chen, 2015; Rasoolimanesh ve diğerleri, 2017b; Ribeiro ve diğerleri, 2017). Yerel turizm gelişimine yönelik desteğini ölçmek amaciyla Ekici ve Çizel (2014) ve Güneş (2014)'ün çalışmalarında kullanılan dört ifadeden oluşan tek boyutlu ölçek kullanılmıştır.

\subsection{Araştırma Modeli ve Hipotezleri}

İlişkisel türde tasarlanan bu araştırmada da yer kimliği, yer imajı, yerel halkın turizm gelişimine yönelik algı ve desteği arasındaki ilişkiyi incelemeye yönelik oluşturulan simgesel model Şekil 1' de yer almaktadır.

Şekil 1:Araştırmanın Simgesel Modeli

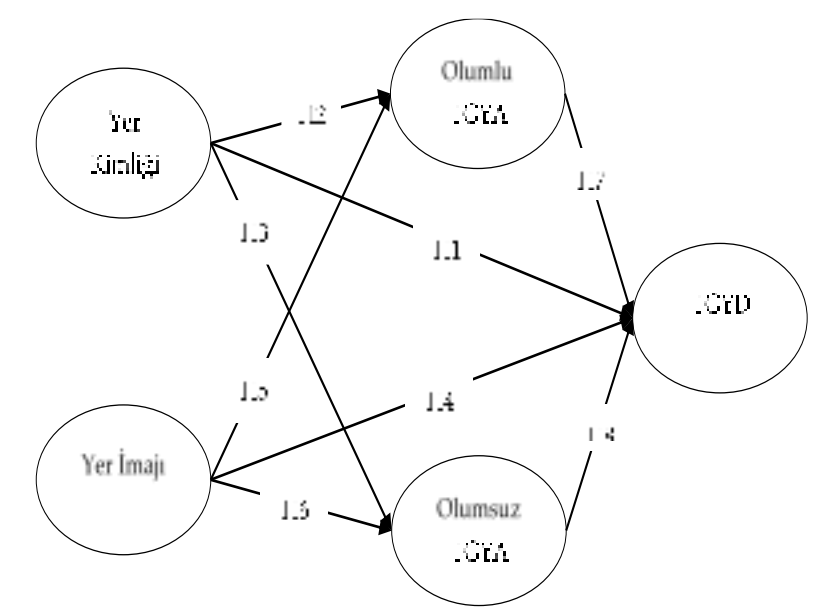

Yer kimliği teorisine göre bir bireyin kimliğinin davranışlarını ve tutumlarını etkilediği varsayılmaktadır (Stets ve Bigga, 2003). Alanyazında yapılan çalışmalarda da yer kimliği ile yerel halkın algılanan olumlu ve olumsuz etkileri ve turizme yönelik desteği arasında önemli ilişkiler gözlemlenmiştir (Wang ve $\mathrm{Xu}, 2015$; Wang ve Chen, 2015). Dolayısı ile yer kimliği, yerel halkın turizme yönelik algılarını etkilemede aktif rol oynamaktadır. Bu doğrultuda H1, H2 ve H3 hipotezleri oluşturulmuştur.

H1: Yer kimliğinin, yerel halkın turizm gelişimine yönelik desteği üzerinde anlamlı bir etkisi vardır.

H2: Yer kimliğinin, turizm gelişimine yönelik olumlu algıları üzerinde anlamlı bir etkisi vardır.

H3: Yer kimliğinin, turizm gelişimine yönelik olumsuz algıları üzerinde anlamlı bir etkisi vardır.

Yerel halkın, turizm planlama sürecindeki önemli rolünden dolayı, yer imajı algıları da önemli görülmektedir (Stylidis ve diğerleri, 2015). Ayazlar (2016), Ramkisson ve Nunkoo (2011), Stylidis ve diğerleri (2014), Stylidis ve diğerleri (2015) de çalışmalarında yerel halkın yer imaj algılarının, yerel halkın turizme yönelik algılarını ve desteğini etkilediğini öne sürmektedir. Bu noktadan hareketle yer imajı, yerel turizm gelişimine yönelik alg1 ve desteği ile ilgili H4, H5 ve H6 hipotezleri geliştirilmiştir.

H4: Yer imajının, yerel halkın turizm gelişimine yönelik desteği üzerinde anlamlı bir etkisi vardır.

H5: Yer imajının, yerel halkın turizm gelişimine yönelik olumlu algıları üzerinde anlamlı bir etkisi vardır.

H6: Yer imajının, yerel halkın turizm gelişimine yönelik olumsuz algıları üzerinde anlamlı bir etkisi vardır.

SDT' ne göre yerel halkın turizm gelişimine yönelik desteğinin ve katılımının sağlanmasında en önemli belirleyici, yerel halkın turizmin etkilerine yönelik algısıdır. Ko ve Stewart (2002), Gursoy ve diğerleri (2019), Lee (2013) ve Wang ve Pfister (2008) çalışmalarında yerel halkın turizmin gelişimine yönelik olumlu ve olumsuz algılarının, turizm gelişimine yönelik desteğini etkilediği ortaya çıkmıştır. Bu öngörüye dayanarak turizm gelişimine yönelik olumlu ve olumsuz algıları ile turizm gelişimine yönelik desteği arasındaki ilişkiye yönelik $\mathrm{H} 7$ ve $\mathrm{H} 8$ hipotezi geliştirilmiştir. 
H7: Turizm gelişimine yönelik olumlu algıların (ekonomik, sosyal, kültürel), yerel halkın turizm gelişimine yönelik desteği üzerinde anlamlı bir etkisi vardır.

H8: Turizm gelişimine yönelik olumsuz algıların (sosyal, kültürel), yerel halkın turizm gelişimine yönelik desteği üzerinde anlamlı bir etkisi vardır.

\section{Analiz ve Bulgular}

Araştırmada kullanılan ölçeklerin yapı geçerliliğini belirlemek için doğrulayıcı faktör analizi (DFA) ve değişkenler arası ilişkileri saptamak amacıyla yapısal eşitlik modellemesi (YEM) kullanılmıştır. $\mathrm{Bu}$ analizler gerçekleştirmek amacıyla IBM SPSS 22 (Statistical Package for the Social Sciences) ve AMOS 20 (Analysis of Moment Structures) paket programları kullanılmıştır.

Katılımcıları sosyo-demografik özelliklerini belirlemek amaciyla yaş, cinsiyet, medeni durum, eğitim durumu, Adıyamanlı olup olmama, gelir durumu, çalışma durumu ve ikamet süresini belirlemek amaciyla frekans analizi yapılmıştır. Yaş değişkenine ilişkin soru açık uçlu sorulmuş, sonrasında ise gruplandırma yapılmıştır. Çalışma durumu ve ikamet süresi ifadelerinde ise homojen dağılım sağlanması amacıyla yeniden gruplandırma yapılmıştır. Yerel halkın sosyo-demografik özelliklerine yönelik bulgular Tablo 1'de yer almaktadır.

Tablo 1: Katılımcıların Sosyo-Demografik Özellikler Açısından Dağılımı

\begin{tabular}{|c|c|c|}
\hline & Sayı & Yüzde \\
\hline \multicolumn{3}{|l|}{ Yaş } \\
\hline $18-25$ yaş & 224 & 32.1 \\
\hline $26-35$ yaş & 232 & 33.2 \\
\hline $36-45$ yaş & 161 & 23.1 \\
\hline 46 yaş ve üstü & 81 & 11.6 \\
\hline Toplam & 698 & 100 \\
\hline \multicolumn{3}{|l|}{ Cinsiyet } \\
\hline Kadın & 309 & 44.3 \\
\hline Erkek & 389 & 55.7 \\
\hline Toplam & 698 & 100 \\
\hline \multicolumn{3}{|l|}{ Medeni Durum } \\
\hline Evli & 394 & 56.4 \\
\hline Bekar & 304 & 43.6 \\
\hline Toplam & 698 & 100 \\
\hline \multicolumn{3}{|l|}{ Eğitim Durumu } \\
\hline İlköğretim & 69 & 9.65 \\
\hline Lise & 248 & 34.89 \\
\hline Önlisans & 81 & 11.77 \\
\hline Lisans & 239 & 34.47 \\
\hline Lisansüstü & 61 & 9.22 \\
\hline Toplam & 698 & 100 \\
\hline \multicolumn{3}{|l|}{ Doğum Yeri } \\
\hline Adiyaman & 581 & 83.20 \\
\hline Diğer & 117 & 16.80 \\
\hline Toplam & 698 & 100 \\
\hline \multicolumn{3}{|l|}{ Gelir Durumu } \\
\hline 1605 TL ve Alt1 & 152 & 21.80 \\
\hline $1606-2606 \mathrm{TL}$ & 171 & 24.50 \\
\hline $2607-3607 \mathrm{TL}$ & 125 & 17.90 \\
\hline $3608-4608 \mathrm{TL}$ & 119 & 17.00 \\
\hline 4609 TL ve üstü & 131 & 18.80 \\
\hline Toplam & 698 & 100 \\
\hline \multicolumn{3}{|l|}{ Çalışma Durumu } \\
\hline Kamu Sektörü & 243 & 34.80 \\
\hline Özel Sektör & 178 & 25.50 \\
\hline
\end{tabular}

\begin{tabular}{lcr}
\hline $\begin{array}{l}\text { Serbest/Üretime } \\
\text { Katılmayan }\end{array}$ & 277 & 39.7 \\
\hline Toplam & 698 & 100 \\
\hline İkamet Süresi & & \\
\hline 15 y1ldan az & 170 & 24.4 \\
\hline $16-25$ y1l & 223 & 31.9 \\
\hline 26 y1l ve üzeri & 305 & 43.7 \\
\hline Toplam & 698 & 100 \\
\hline
\end{tabular}

Örneklemin yaş gruplarına göre dağılımı incelendiğinde katılımcıların büyük bir çoğunluğunun genç ve orta yaş grubunda olduğu söylenebilir. Katılımcıların cinsiyet ve medeni durum açısından dağılımının, normal dağılıma yakın olduğu söylenebilir. Eğitim durumu incelendiğinde ise katılımcıların büyük çoğunluğunun lise ve lisans mezunu olduğu görülmektedir. Bu durum genç ve orta yaş grubu sayısının fazla olması ile açıklanabilir.

Ortalama aile geliri bakımından incelendiğinde ise en fazla katılımcının 1606-2606 TL gelir grubundan olduğu görülmektedir. Diğer gelir gruplarında ise katılımcıların eşit bir şekilde dağılım gösterdiği söylenebilir. Katılımcıların çalışma durumlarına göre dağılımları incelendiğinde \%34.80'i kamu çalışanı, \%25.50'si özel sektör ve \%39.70’i ise serbest/üretime katılmayan diğer bir deyişle ev hanımı, öğrenci, emekli, çalışmayanlardan oluşmaktadır. Bu durum yine katılımcıların genç yaş grubunda olması ile açıklanabilir. Katılımcıların büyük çoğunluğunu Adıyamanlılar oluşturmaktadır. Örneklem grubu ikamet süresi bakımından incelendiğinde ise katılımcıların çoğunluğunun 26 yıldan fazla bir süredir Adıyaman'da ikamet ettiği görülmektedir. $\mathrm{Bu}$ durum katılımcıların çoğunun Adıyamanlı olması ile açıklanabilir.

Araştırma modeli ve hipotezlerini test etmeye yönelik analizlere başlamadan önce verilerin analize hazır olması için her bir veri göz yordamı ile kontrol edilmiştir. Buna bağlı olarak eksik veya hatalı olduğu belirlenen 42 adet veri değerlendirme dışı bırakılmıştır. İleri analizlere geçmeden önce değişkenlerin dağılımları, çarpıklık ve basıklık değerleri incelenmiştir. Olumlu TGYA (Turizm Gelişimine Yönelik Alg1) ve TGYD (Turizm Gelişimine Yönelik Destek) değişkenlerinin çarpıklık değerlerinin $+/$ - 1 sınırları dışında kaldığı görülmüştür. Ardından tüm değişkenler Z puana çevrilerek + / - 3.29 sınırları dışında kalan katılımcıların olup olmadığı incelenmiştir. Olumlu TGYA ve TGYD değişkenlerinde bu sınırların dişında kalan toplam 33 katılımcı tespit edilmiştir. Bu uç değerlere sahip katılımcıların sayısı tüm örneklemin \%5'inden (33 katılımcı) az olduğu için analizden çıkarılmalarına karar verilmiştir. Analizler sonucunda 698 veri değerlendirmeye alınmıştır.

DFA sonucunda faktör yüklerinin 0,50'nin altında olması nedeni ile yer imajı ölçeğinden 5 madde ve TGYA ölçeğinden 4 madde analiz dışı bırakılmıştır. Ölçüm modelinin DFA sonuçlarına ilişkin faktör yükleri, BYG (Birleşme Yapı Güvenirliliği), OAV (Ortalama Açıklanan Varyans) ve CA (Cronbach's Alpha) değerleri ile R ${ }^{2}$ (Her bir ifadenin faktörü açıklama gücü) değerleri Tablo 2'de yer almaktadır. Elde edilen tüm değerler ölçüm modelinin yakınsak geçerliliğinin sağlandığını göstermektedir (Fornell ve Larcker, 1981; Hair ve diğerleri, 2010). OAV'nin karekökü, tüm yapılar için korelasyonlarından daha büyük olmasından dolayı ölçüm modelinin ayırt edici geçerliliği sağlanmıştır. 
Tablo 2: Ölçüm Modeli DFA Sonuçları

\begin{tabular}{|c|c|c|c|c|c|c|}
\hline Faktörler & Ort. & Standart Yükler & $\mathrm{R}^{2}$ & BYG & OAV & $\mathrm{CA}$ \\
\hline Yer Kimliği & 3,42 & & & 0,82 & 0,55 & 0,90 \\
\hline Ayırt edicilik & & 0,71 & 0,50 & & & \\
\hline Süreklilik & & 0,81 & 0,65 & & & \\
\hline Öz sayg1 & & 0,77 & 0,60 & & & \\
\hline Öz yeterlilik & & 0,67 & 0,44 & & & \\
\hline Yer İmajı & 2,87 & & & 0,79 & 0,56 & 0,87 \\
\hline Fiziksel Görünüş & & 0,66 & 0,43 & & & \\
\hline Sosyal Olanaklar & & 0,83 & 0,69 & & & \\
\hline Kamusal Olanaklar & & 0,75 & 0,56 & & & \\
\hline Olumlu TGYA & 4,50 & & & 0,76 & 0,52 & 0,81 \\
\hline Olumlu Sosyal Etki & & 0,65 & 0,41 & & & \\
\hline Olumlu Ekonomik Etki & & 0,61 & 0,37 & & & \\
\hline Olumlu Kültürel Etki & & 0,69 & 0,47 & & & \\
\hline Olumsuz TGYA & 2,50 & & & 0,84 & 0,64 & 0,81 \\
\hline Olumsuz TGYAP1 & & 0,82 & 0,64 & & & \\
\hline Olumsuz TGYAP2 & & 0,79 & 0,61 & & & \\
\hline Olumsuz TGYAP3 & & 0,80 & 0,64 & & & \\
\hline TGYD & 4,72 & & & & & \\
\hline $\begin{array}{l}\text { Bölgemizde turizmin gelişmesi için daha fazla çaba sarf } \\
\text { edilmelidir. }\end{array}$ & & 0,69 & 0,48 & 0,84 & 0,57 & 0,83 \\
\hline Turizm yatırımları artarak devam etmelidir. & & 0,81 & 0,66 & & & \\
\hline Adıyaman'da turizm gelişimini destekliyorum. & & 0,82 & 0,66 & & & \\
\hline Turizm, toplumumuzun bir parçası olmalıdır. & & 0,70 & 0,49 & & & \\
\hline
\end{tabular}

edilen sonuçlar ölçüm modelinin veri ile iyi uyum

Tablo 3: Ölçüm Modeli Uyum Değerleri

\begin{tabular}{lllll}
\hline Uyum İndeksi & İyi Uyum & Kabul Edilebilir Uyum & $\begin{array}{l}\text { Araştırma } \\
\text { Değeri }\end{array}$ & Uyum \\
\hline$\chi 2 / \mathrm{df}$ & $0 \leq \chi 2 / \mathrm{df} \leq 3$ & $3<\chi 2 / \mathrm{df} \leq 5$ & 2,41 & İyi Uyum \\
\hline RMSEA (Yaklaşık hataların ort.karekökü) & $0 \leq \mathrm{RMSEA} \leq 0,05$ & $0,05<\mathrm{RMSEA} \leq 0,08$ & 0,04 & İyi Uyum \\
\hline NFI (Normlaştırılmış uyum indeksi) & $0,95 \leq \mathrm{NFI} \leq 1,00$ & $0,90 \leq \mathrm{NFI}<0,95$ & 0,95 & İyi Uyum \\
\hline CFI (Karşılaştırmalı uyum indeksi) & $0,97 \leq \mathrm{CFI} \leq 1,00$ & $0,95 \leq \mathrm{CFI}<0,97$ & 0,97 & İyi Uyum \\
\hline GFI (İyilik uyum indeksi) & $0,90 \leq \mathrm{GFI} \leq 1,00$ & $0,85 \leq \mathrm{GFI}<0,90$ & 0,99 & İyi Uyum \\
\hline AGFI (Düzeltilmiş iyililk uyum indeksi) & $0,90 \leq \mathrm{AGFI} \leq 1,00$ & $0,85 \leq \mathrm{AGFI}<0,90$ & 0,94 & İyi Uyum \\
\hline Geçerliliği ve güvenirliği istatiksel olarak anlamlı olarak $\quad$ kontrol edilmiștir Elde edilen sonuçlar yapısal esitlik
\end{tabular}

Geçerliliği ve güvenirliği istatiksel olarak anlamlı olarak kontrol edilmiştir. Elde edilen sonuçlar yapısal eşitlik sonuçlanan değişkenler arasında daha önceden oluşturulan modelinin veri ile iyi uyum gösterdiğine işaret etmektedir. hipotezler YEM ile test edilmiştir. Hipotezlere yönelik Model uyum indekslerine Tablo 4'den ulaşılabilir. değerlendirmeden önce modele ilişkin uyum değerleri

Tablo 4: Yapısal Eşitlik Modeli Uyum İyiliği Değerleri

\begin{tabular}{lllll}
\hline Uyum İndeksi & İyi Uyum & Kabul Edilebilir Uyum & Araştırma Değer & Uyum \\
\hline$\chi^{2} / \mathrm{df}$ & $0 \leq \chi^{2} / \mathrm{df} \leq 3$ & $3<\chi 2 / \mathrm{df} \leq 5$ & 2,625 & İyi Uyum \\
\hline RMSEA & $0 \leq \mathrm{RMSEA} \leq 0,05$ & $0,05<\mathrm{RMSEA} \leq 0,08$ & 0,04 & İyi Uyum \\
\hline NFI & $0,95 \leq \mathrm{NFI} \leq 1,00$ & $0,90 \leq \mathrm{NFI}<0,95$ & 0,94 & Kabul Edilebilir Uyum \\
\hline CFI & $0,97 \leq \mathrm{CFI} \leq 1,00$ & $0,95 \leq \mathrm{CFI}<0,97$ & 0,96 & Kabul Edilebilir Uyum \\
\hline GFI & $0,90 \leq \mathrm{GFI} \leq 1,00$ & $0,85 \leq \mathrm{GFI}<0,90$ & 0,95 & İyi Uyum \\
\hline AGFI & $0,90 \leq \mathrm{AGFI} \leq 1,00$ & $0,85 \leq \mathrm{AGFI}<0,90$ & 0,94 & İyi Uyum
\end{tabular}

Model ayrıntılı olarak incelendiğinde, yer kimliğinin turizm gelişimine yönelik olumlu algılarını $(\beta=.35, \mathrm{p}<.001)$; yer imajının ise turizm gelişimine yönelik olumsuz algılarını pozitif yönde ve anlamlı olarak etkilemektedir $(\beta=.25, \mathrm{p}<$. 05). Buna ek olarak turizm gelişimine yönelik olumlu algıların, turizme yönelik desteği pozitif düzeyde ve anlamlı olarak $(\beta=.69, \mathrm{p}<.001)$; turizm gelişimine yönelik olumsuz algılarının ise turizme yönelik desteği negatif düzeyde ve anlamlı olarak etkilemektedir $(\beta=-.14$, $\mathrm{p}<$. 05). Buna karşın yer kimliğinin turizm gelişimine yönelik olumsuz algıları ve turizme yönelik desteği; yer imajının da turizm gelişimine yönelik olumlu algıları ve 
turizme yönelik desteği anlamlı olarak etkilemediği bulunmuştur (bkz., Şekil 2).

Şekil 2: Yapısal Eşitlik Modeli

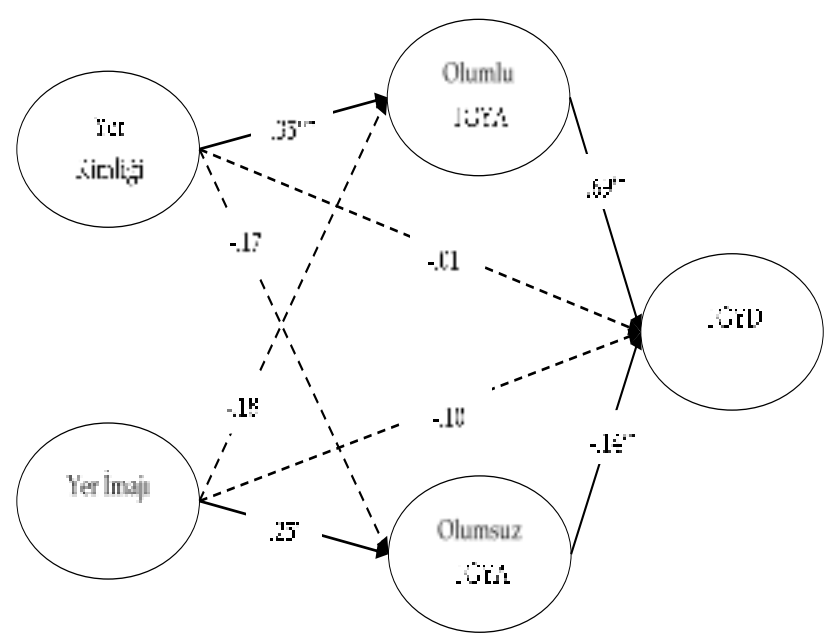

$\mathrm{R}^{2}$ değerleri, modelde yer alan değişkenler arasındaki etkilerin açıklanma gücünü ifade etmektedir. Şekil 2'den de izlenebileceği gibi yer kimliği, turizm gelişimine yönelik olumlu algılarındaki varyansın \% 5'ini, yer imajı ise turizm gelişimine yönelik olumsuz algılarındaki varyansın \% 2'sini açıklamaktadır. Ayrıca turizmin algılanan olumlu ve olumsuz etkileri, yerel halkın turizme yönelik verdiği destekteki varyansın \% 50'sini açıklamaktadır. Araştırma modeli doğrultusunda oluşturulan $\mathrm{H} 2, \mathrm{H} 5, \mathrm{H} 7$ ve $\mathrm{H} 8$ hipotezleri desteklenmiştir. H1, H3, H4, H6 hipotezleri ise anlamlı t-değerlerine sahip olmamalarından dolayı desteklenmemiştir. Ayrıca YEM'e geçilmeden önce yer kimliği ve yer imajının TGYD üzerinde doğrudan etkisi olup olmadığı sınanmıştır. Yapılan analizde her ikisinin de YEM'de olduğu gibi TGYD üzerinde doğrudan etkisi olmadığı görülmüştür. $\mathrm{Bu}$ nedenle yer kimliği ve yer imajının TGYD üzerinde dolaylı etkisi olduğunu söylemek mümkündür.

\section{Sonuç ve Öneriler}

Turistik bölgelerde yaşayan yerel halkın, yaşadıkları yere yönelik memnuniyet düzeyleri, turizmin gelişimine yönelik planları etkileyebilmektedir. $\mathrm{Bu}$ noktada önemli birer değişken olarak beliren yer kimliği ve yer imajı da yerel halkın yere yönelik memnuniyetinde kritik öncüller olmaktadır. $\mathrm{Bu}$ nedenle, yerel halkın yere yönelik algılarının belirlenmesi, turizm gelişimine yönelik kamu desteğini sağlamada etkili olup, yerel halkın aktif desteği, başarılı ve sürdürülebilir turizm gelişimine zemin hazırlamaktadır. $\mathrm{Bu}$ bağlamda çalışmada Türkiye'nin önemli kültür turizmi destinasyonlarından olan Adıyaman'da yerel halkın turizm gelişimine yönelik desteğinde yer kimliği ve yer imajının rolü belirlenmiştir.

Araştırma amacı doğrultusunda oluşturulan yapısal modelin analizi sonucunda yer kimliğinin olumlu TGYA'y1 pozitif yönlü ve anlamlı düzeyde etkilediği, olumsuz TGYA'yı ise etkilemediği belirlenmiştir. Bununla birlikte yer kimliğinin TGYD'ni doğrudan etkilemediği ancak dolaylı olarak etkilediği söylenebilir (bkz., Şekil 2). Bu noktada elde edilen sonuç Wang ve Xu (2015) ile Wang ve Chen (2015) çalışmaları ile örtüşmektedir. Çalışmalarda yer kimliğinin, hem olumlu TGYA'yı hem de olumsuz TGYA'yı etkilemede aktif rol oynadığı, yerel halkın TGYD'inde de aracı rol oynadığı görülmüştür.

Stylidis ve diğerleri (2014) ile Ramkisson ve Nunkoo (2011)'nın yer imajı ile yerel halkın turizm gelişimine yönelik desteği ile ilgili yapılan çalışmalarda yer imajının turizme yönelik desteği doğrudan etkilediği ortaya çıkmıştır. Bu çalışmada ise yer imajının olumlu TGYA'yı etkilemediği, olumsuz TGYA'yı ise pozitif yönlü ve anlamlı bir düzeyde etkilediği saptanmıştır. Yer imajının TGYD'ni doğrudan etkilemediği ancak olumsuz TGYA üzerinden dolaylı olarak etkilediği söylenebilir. Yerel halkın yer imajı algısı arttıkça turizme yönelik olumsuz algıSı artmaktayken, turizm gelişimine yönelik desteği de artmaktadır. Bu sonucun Adıyaman'daki toplumsal yaşam çerçevesi içinde oluşması şaşırtıcı değildir. Açıkçası bir konu hakkında imajın rolü tartış1ırken, imaj kavramının bölgesel parametrelerini yeniden anlamlandırmak gerekmektedir. Nitekim imaj, yaşam tarzı, yaşanılan çevre, arka planda gelişen olaylar veya belirgin kişiler ile manipüle olabilmektedir (Dichter, 1985).

Turizme yönelik toplum desteğinin yerel halkın turizm gelişimine yönelik algılarına bağlı olmasından dolayı çalışmada yerel halkın turizm gelişimine yönelik desteği SDT ile açıklanmaya çalışılmıştır. Analizler sonucunda olumlu TGYA'nın TGYD'i pozitif yönlü olarak ve olumsuz TGYA'nın ise TGYD'i negatif yönlü olarak etkilediği saptanmıştır. Araştırmanın bu sonucu, Çiçek ve Sarı (2018), Ekici ve Çizel (2014), Eusébio ve diğerleri (2018), Gursoy ve Rutherford (2004), Gursoy ve diğerleri (2017), Latkova ve Vogt (2012), Martín ve diğerleri (2018), Rasoolimanesh ve diğerleri (2017b), Vargas-Sanchez ve diğerleri (2015) çalışmalarında olduğu gibi ulusal ve uluslararası alanyazında yapılan birçok araştırmanın sonucu ile örtüşmektedir. Bunun yanı sıra Peštek ve diğerlerinin (2019) de Bosna-Hersek'de yaptıkları çalışmada yerel halkın turizme yönelik destek verdiği ortaya çıkmıştır. $\mathrm{Bu}$ desteğin ise yerel halkın turizm gelişimine yönelik olumlu algılarının arttıkça ve/veya olumsuz algılarının azaldıkça devam etmesi beklenmektedir.

Dünya miras alanlarına sahip bölgelerde yaşayan toplumların turizmin gelişimine yönelik desteği ve katılımının sağlanması, dünya mirası alanlarının korunmasının ve destinasyonların sürdürülebilir gelişiminin ön koşullarındandır (Rasoolimanesh ve diğerleri, 2017a). Adıyaman'da da turizminin doğru ve güçlü planlanması ile turizm gelişiminin ivme kazanacağı düşünülmektedir. Bu noktada paydaş gruplarının planlama sürecine katılımı ile turizm planlamasının uygulanabilir olması önem arz etmektedir. Yüksek kültür turizmi potansiyeline sahip Adıyaman'da yerel halkın yer kimliği, yer imajı ve turizm etkilerine yönelik algılarının, turizme yönelik desteğinin anlaşılmasında birbirlerini tamamlayıcı bir rol üstlenmektedir. Yerel halkın turizmin etkilerine yönelik fayda ve maliyet dengesinin sağlanmasında yer kimliği ve yer imajı algılarının arttırılması, Adıyaman'da başarılı bir turizm gelişimi için önemlidir.

Yerel halkın Adıyaman'a yönelik imaj algılarının güçlendirilmesi için bölgenin sosyal olanaklarının ve kamusal olanaklarının geliştirilmesi gerekmektedir. $\mathrm{Bu}$ nedenle, yerel halkın boş zamanlarını değerlendirebilecekleri faaliyetlerin yapılması ve rekreasyon alanların oluşturulması, mevcut yiyecek-içecek 
işletmelerinin kalitesinin arttırılması ve yeni girişimlere teşvik sağlanması gerekmektedir. Buna ek olarak alışveriş olanaklarının arttırılmasının ve iyileştirilmesinin de yer imajı algısına katkı sağlayacağı düşünülmektedir. Adıyaman'da kamusal olanaklara yönelik olumlu algıların arttırılması için toplu taşıma ve sağlık hizmetleri için gerekli alt ve üst yatırımlarının güçlendirilmesi önemlidir. Aynı zamanda bölgenin iş bulma olanakları bakımından zayıf olması, yer imajı algılarının düşmesine neden olmaktadır. Adıyaman'da turizm faaliyetlerinin geliştirilmesi ile birlikte istihdam olanaklarının artması beklenmektedir. $\mathrm{Bu}$ yönde yapılacak yatırımlar bölgede kentsel gelişim sağlamada stratejik adımlardır. Planlamalar yapılırken yerel halkın beklentilerine yönelik hizmetlerin yapılması ile etkili bir yer imajı oluşacaktır. Bunun için yerel yönetimlerin merkezi yönetimler tarafindan güçlendirilmesi ve yetki aktarımıyla daha güçlü kararlar alınması gereklidir. Bu sayede yerel halkın Adıyaman ile ilgili imaj algılarının değişmesi birlikte yerleşmek ve ziyaret etmek için daha elverişli ve çekici bir bölge olması beklenmektedir.

Kemmis (1990) 'a göre insanların belirli bir yeri kendi ile özdeşleştirmesi ve yere bağlılık duygusu hissetmesi, bu yerin fiziksel çevreye yönelik imaj algılarına bağlı olduğunu belirtmektedir. Stylidis (2018), Yunanistan'ın Kavala kentinde yerel halkın yere bağlılık, yer imajı ve turizm desteği arasındaki ilişkiyi incelediği çalışmasında da aynı sonuca ulaşmıştır. Bu noktada yerel halkın olumlu yer imajı algısının sağlanması ile yer kimliği algısının da etkileneceği düşünülmektedir.

Çalışmada elde edilen önemli bulgulardan biri de, Adıyaman merkez mahallelerinde yaşayan yerel halkın turizm gelişimine yönelik desteğinin oldukça yüksek olmasıdır. Katılımcılar, Adıyaman'da turizm gelişiminin bölgeyi olumlu yönde etkileyeceğini düşünmektedirler. Böylece yerel halkın turizme yönelik mesafeli olduğu kanısının geçersiz olduğu söylenebilir. Yerel halkın turizmin olumlu etkilerine yönelik algıları artıkça turizmin gelişimini hoşgörülü karşılaması beklenmektedir. Turizmin etkilerine yönelik algılardaki olumlu değişim yerel halkın turizm faaliyetlerine destek vermesini sağlarken, olumsuz değişim ise yerel halkın turizm faaliyetlerine destek vermemesine veya karşı çıkmasına neden olabilir. Yerel halk turizmin bölgeyi sosyal, çevresel ve kültürel anlamda olumsuz etkileyeceğini de düşünmektedir. $\mathrm{Bu}$ doğrultuda turizm gelişimine yönelik planlamalar, sosyal çevreye ve yerel kültüre zarar vermeden gerçekleştirilmelidir. Adıyaman'ın yöresel ürünlerini ve el sanatlarını ortaya çıkaracak çalışmaların yapılması ve daha geniş kitlelere tanıtılması amaciyla festivaller düzenlenmesi bölge turizminin gelişimine yarar sağlayacaktır. Bunun gerçekleştirilmesi için yerel yönetimler, özel sektör ve üniversite arasında iş birliğinin olması fayda sağlayacaktır.

Çalışmada yerel halkın turizm gelişimine yönelik algı ve desteği, sadece yer kimliği ve yer imajı değişkenleri arasındaki ilişki incelenmiştir. Yerel halkın turizme yönelik desteğinde etkili olan yaşam tatmini, sosyal kimlik gibi farklı değişkenlerin belirlenmesi, bölgedeki turizmin planlaması açısından önemlidir. Çalışmada sadece yerel halkın yer kimliği ve yer imajı algıları ortaya çıkarılmıştır. $\mathrm{Bu}$ nedenle, yer kimliği ve yer imajı algılarının belirlenmesinde bölgeye gelen ziyaretçilerin de değerlendirilmesi turizm plan ve politikaları için daha faydalı olacaktır. Bu bakımdan turistlerin yer kimliği, yer imajı ve yere bağlılık gibi algılarının davranışsal niyetlere olan etkisinin incelenmesi, Adıyaman turizmi açısından önemlidir. Son olarak, araştırmanın neden-sonuç ilişkisi Adıyaman özelinde değerlendirilmelidir. Her bölgenin turistik yaşam döngüsünün farklı olmasından dolayı araştırmanın sonuçlarının diğer turistik bölgelerde farklılık göstereceği beklenmektedir. Bu nedenle farklı bölgelerde araştırmaların yapılması önerilmektedir.

\section{Kaynakça}

Acar, S., Meydan, M.C., Bilen Kazancık, L. \& Işık, M. (2019). Illerin ve bölgelerin sosyo-ekonomik gelişmişlik sıralaması araştırması. Ankara: Kalkınma Ajansları Genel Müdürlüğü Yayını.

Adıyaman Valiliği (2017). Adıyaman nüfus bilgileri. http://www.adiyaman.gov.tr/nufus-bilgileri (erişim taihi:05.05.2018).

Almeida-García, F., Peláez-Fernández, M. Á., BalbuenaVazquez, A. \& Cortes-Macias, R. (2016). Residents' perceptions of tourism development in Benalmádena (Spain). Tourism Management, 54, 259-274.

Argan, M., Sabri, K. A. Y. A., Argan, M. T., Akyıldız, M. \& Korkmaz, T. (2015). Relationship between place attachment and event satisfaction: a study on university students. Journal of Sport and Social Sciences, 2(2), 115.

Ayazlar, G., Aslan, S. ve Çörüş, H.A. (2015). Nereden bilelim? kimliğinde turizmci mi yazıyor? yerel halk ve sosyal kimlik teorisi, 16. Ulusal Turizm Kongresi, Çanakkale 18 Mart Üniversitesi 12-15 Kasım 2016. Çanakkale. ss. 844-858

Arslan-Ayazlar, R. ve Ayazlar, G. (2016). Yerel halkın turizmin etkilerine yönelik tutumunda aidiyet duygusu ve yaşam tatmininin rolü. Atatürk Üniversitesi Sosyal Bilimler Enstitüsü Dergisi, 20(4), 1451-1470.

Ayazlar, G. (2016). Yerel halkın turizm etkilerine yönelik tutumlarını anlamak: yerel halkın bölge imajı ve bölge desteği. Uluslararası Sosyal Araştırmalar Dergisi, 9(43), 2538-2547.

Boley, B. B., McGehee, N. G., Perdue, R. R. \& Long, P. (2014). Empowerment and resident attitudes toward tourism: strengthening the Theoretical Foundation Through A Weberian Lens. Annals of Tourism Research, 49, 33-50.

Chen, S., Wang, S. \& Xu, H. (2017). Influence of place identity on residents' attitudes to dark tourism. Journal of China Tourism Research, 13(4), 338-356.

Çiçek, D. ve Sarı, Y. (2018). Yerel halkın turizme olan desteği: Türkiye'deki sakin şehirler üzerine bir araştırma. Anatolia: Turizm Araştırmaları Dergisi, 29(2), 185-196.

Dedeoğlu, B.B., Çamlıca, K., Karakuş, Y. ve Birinci, M.C. (2018). Yerel halkın turizmin fayda ve maliyetlerine ilişkin algllamalarında bölge aidiyetinin belirleyiciliği: kapadokya örneği, 7. Ulusal (III. Uluslararası) Doğu Akdeniz Turizm Sempozyumu, İskenderun Teknik Üniversitesi 20-21 Nisan 2018. Hatay. ss: 862-867. 
Dichter, E. (1985). What's in an image. Journal of Consumer Marketing, 2(1), 75-81.

Ekici, R. ve Çizel, B. (2014). Yerel halkın turizm gelişimi desteğine ilişkin tutumlarının destinasyonların gelişme düzeyine göre farklılıkları. Seyahat ve Otel Işletmeciliğ $i$ Dergisi, 11(3), 73-87.

Erkorkmaz, Ü., Etikan, İ., Demir, O., Özdamar, K. ve Sanisoğlu, S.Y. (2013). Doğrulayıcı faktör analizi ve uyum indeksleri. Türkiye Klinikleri, 30(1), 210-223.

Eusébio, C., Vieira, A. L. \& Lima, S. (2018). Place attachment, host-tourist interactions, and residents' attitudes towards tourism development: The Case of Boa Vista Island in Cape Verde. Journal of Sustainable Tourism, 26(6), 890-909.

Faulkner, B. \& Tideswell, C. (1997). A framework for monitoring community impacts of tourism. Journal of Sustainable Tourism, 5 (1), 3-28.

Garcia, J. A., Gomez, M. \& Molina, A. (2012). A destination-branding model: an empirical analysis based on stakeholders. Tourism Management, 33 (3), 646-661.

Göregenli, M. (2013). Çevre psikolojisi: insan-mekan ilişkileri. İstanbul: İstanbul Bilgi Üniversitesi Yayınları.

Göregenli, M., Karakuş, P., Kösten, E. Y. Ö. ve Umuroğlu, I. (2014). Mahalleye bağlılık düzeyinin kent kimliği ile ilişkisi içinde incelenmesi. Türk Psikoloji Dergisi, 29(73), 73-85.

Goeldner, C. R. \& Ritchie, J. R. B. (2002). Tourism: principles, practices. Philosophiesn New Jersey: John Wiley and Sons.

Gu, H. \& Ryan, C. (2008). Place attachment, identity and community impacts of tourism - The Case of a Beijing Hutong. Tourism Management, 29, 637-647.

Gursoy, D., \& Rutherford, D. G. (2004). Host attitudes toward tourism: an improved structural model. Annals of Tourism Research, 31(3), 495-516.

Gursoy, D., Ouyang, Z., Nunkoo, R., \& Wei, W. (2019). Residents' impact perceptions of and attitudes towards tourism development: a meta-analysis. Journal of Hospitality Marketing \& Management, 28 (3), 306-333.

Hadinejad, H. Moyle, B.D., Scott, N., Kralj, A. \& Nunkoo, R. (2019). Residents' attitudes to tourism: a review. Tourism Review, 74 (2).

Haobin-Ye, B., Qiu Zhang, H., Huawen Shen, J. \& Goh, C. (2014). Does social identity affect residents' attitude toward tourism development? an evidence from the relaxation of the individual visit scheme. International Journal of Contemporary Hospitality Management, 26(6), 907-929.

Hernández, B., Hidalgo, M. C., Salazar-Laplace, M. E. \& Hess, S. (2007). Place attachment and place identity in Natives and ;Non-natives. Journal of Environmental Psychology, 27(4), 310-319.

Hidalgo, M. C., \& Hernández, B. (2001). Place attachment: conceptual and empirical questions. Journal of Environmental Psychology, 21(3), 273-281.
Kemmis, D. (1990). Community and the politics of place. Norman: University of Oklahoma Press.

Ko, D. W., \& Stewart, W. P. (2002). A structural equation model of residents' attitudes for tourism development. Tourism Management, 23(5), 521-530.

Latkova, P. \& Vogt, C. A. (2012). Residents' attitudes toward existing and future tourism development in rural communities. Journal of Travel Research, 51(1), 50-67.

Lewicka, M. (2010). What makes neighborhood different from home and city? effects of place scale on place attachment. Journal of Environmental Psychology, 30(1), 35-51.

Lee, T. H. (2013). Influence analysis of community resident support for sustainable tourism development. Tourism Management, 34, 37-46.

Marsh, H. W. \& Hocevar, D. A (1998). New, more powerful approach to multitrait-multimethod analyses: application of second-order confirmatory factor analysis. Journal of Applied Psychology, 73(1), 107117.

Martín, H. S., De Los Salmones Sánchez, M. M. G. \& Herrero, Á. (2018). Residents' attitudes and behavioural support for tourism in host communities. Journal of Travel \& Tourism Marketing, 35(2), 231-243.

McCool, S. F. \& Martin, S. R. (1994). Community attachment and attitudes toward tourism development. Journal of Travel Research, 32(3), 29-34.

Nunkoo, R. \& Gursoy, D. (2012). Residents' support for tourism: an identity perspective. Annals of Tourism Research, 39(1), 243-268.

Oğuzbalaban, G. (2017). Türkiye'de yerel halkın turizme ve turizmin etkilerine yönelik algı ve tutumlarına ilişkin yazın taraması. Uluslararası Sosyal Araştırmalar Dergisi, 10(51), 1321-1329.

Oviedo- Garcia, M. A., Castellanos-Verdugo, M. \& MartinRuiz, D. (2008). Gaining residents' support for tourism and planning. International Journal of Tourism Research, 10(2), 95-109.

Peštek, A., Dizdarević, L., Galić, M., \& Arifhodžić, M. (2019). Residents' attitudes toward tourism development: a case study of the Federation of Bosnia and Herzegovina. Društvena İstraživanja. Časopis za Opća Društvena Pitanja, 28(1), 131-151.

Pizam, A., Uriely, N. \& Reichel, A. (2000). The intensity of tourist-host social relationship and its effects on satisfaction and change of attitudes: the case of working tourists in Israel. Tourism Management, 21(4), 395-406.

Ramkissoon, H. \& Nunkoo, R. (2011). City image and perceived tourism impact: evidence from Port Louis, Mauritius. International Journal of Hospitality \& Tourism Administration, 12(2), 123-143.

Rasoolimanesh, S.M., Jaafar, M., Kock, M. (2017). factors on residents' perceptions toward world heritage site inscription and sustainable tourism development. Journal of Sustaniable Tourism, 25 (2), 198-216. 
Rasoolimanesh, S. M., Ringle, C. M., Jaafar, M. \& Ramayah, T. (2017b). Urban vs. rural destinations: residents' perceptions, community participation and support for tourism development. Tourism Management, 60,147-158.

Shumaker, S. A. \& Taylor, R. B. (1983). Toward a clarification of people-place relationships: a model of attachment to place. In N. R. Feimer ve E. S. Geller (Eds), Environmental psychology. Directions and Perspectives, New York: Praeger.

Stets, J. E. \& Bigga, C. F. (2003). Bringing 1dentity theory into environmental sociology. Sociological Theory, 21(4), 398-423.

Strzelecka, M., Boley, B.B., \& Woosnam, K.M. (2017). Place attachment and empowerment: do residents need to be attachment to empowerment. Annals of Tourism Research, 66, 61-73.

Stylidis, D., Biran, A., Sit, J. K. \& Szivas, M. (2014). Residents' support for tourism development: the role of residents' place image and perceived tourism impacts. Tourism Management, 45, 260-274.

Stylidis, D., Belhassen, Y. \& Shani, A. (2015). Three tales of a city: stakeholders' images of Eilat as a tourist destination. Journal of Travel Research, 54(6), 702-716.

Stylidis, D. (2016). The Role of place image dimensions in residents' support for tourism development. International Journal of Tourism Research, 18(2), 129139.

Stylidis, D., Sit, J. K. \& Biran, A. (2016). An exploratory study of place image: the case of Kavala. Journal of Travel Research, 55 (5), 659-674.

Stylidis, D., Shani, A. \& Belhassen, Y. (2017). Testing an integrated destination 1mage model across residents and tourists. Tourism Management, 58, 184-195.

Stylidis, D. (2018). Place attachment, perception of place and residents' support for tourism development. Tourism Planning \& Development, 15(2), 188-210.

Stylos, N., Bellou, V., Andronikidis, A. \& Vassiliadis, C. A. (2017). Linking the dots among destination images, place attachment, and revisit intentions: a study among British and Russian tourists. Tourism Management, 60, 15-29.

Tsai, C. T. (2016). Memorable tourist experiences and place attachment when consuming local food. International Journal of Tourism Research, 18(6), 536548.

Tuan, Y-F. (1977). Space and place: the perspective of experience. Minnepolis: University of Minnesota Press.

Türker, N., Selçuk, Ş. ve Özyıldırım, A. (2016). Turizmin yerel halkın yaşam kalitesi üzerine etkisi: Safranbolu örneği. Karabük Üniversitesi Sosyal Bilimler Enstitüsü Dergisi, 6 (1), 1-13.
Sevim, B., Seçilmiş, C. ve Görkem, O. (2013). Algılanan destinasyon imajının tavsiye davranışı üzerine etkisi: Safranbolu'da bir araştırma. Uluslararası Yönetim İktisat ve İşletme Dergisi, 9(20), 115-129.

Ural, A. ve Kılıç, İ. (2011). Bilimsel araştırma süreci ve SPSS ile veri analizi. Ankara: Detay Yayıncılık.

Uysal, M., Woo, E. \& Singal, M. (2012). The tourist area life cycle (TALC) and its effect on the quality-of-life (QOL) of destination community. In Handbook of Tourism and Quality-of-Life Research (pp. 423-443). Springer, Dordrecht.

Uysal, M., Sirgy, M. J., Woo, E., \& Kim, H. L. (2016). Quality of life (QOL) and well-being research in tourism. Tourism Management, 53, 244-261.

Wang, S. (2016). Roles of place identity distinctiveness and continuity on resident attitude toward tourism. European Journal of Tourism Research, 13, 58-68.

Wang, Y. \& Pfister, R. E. (2008). Residents' attitudes toward tourism and perceived personal benefits in a rural community. Journal of Travel Research, 47(1), 8493.

Wang, S. \& Xu, H. (2015). Influence of place-based senses of distinctiveness, continuity, self-esteem and selfefficacy on residents' attitudes toward tourism. Tourism Management, 47, 241-250.

Wang, S. \& Chen, J. S. (2015). The influence of place identity on perceived tourism impacts. Annals of Tourism Research, 52, 16-28.

Woosnam, K. M. (2011). Comparing residents' and tourists' emotional solidarity with one another: an extension of Durkheim's Model. Journal of Travel Research, 50(6), 615-626.

Woosnam, K. M. (2012). Using emotional solidarity to explain residents' attitudes about tourism and tourism development. Journal of Travel Research, 51(3), 315327.

Yazıcıoğlu, Y. ve Erdoğan, S. (2011). SPSS uygulamal bilimsel araştırma yöntemleri. Ankara: Detay Yayıncilık.

Yeşilyurt, H. ve Koçak, N. (2018). Yerel halkın turizm gelişimine yönelik desteğini inceleyen makalelerin bibliyometrik incelemesi. Van Yüzüncü Yıl Üniversitesi Sosyal Bilimler Enstitüsü Dergisi, Iwact'18 Özel Sayısı, 191-206.

Yılmaz, İ. ve Çalıșkan, C. (2015). Turizm potansiyeli olan bölgelerde toplumsal kapasite algısı: Adıyaman örneği. Journal of Yasar University, 10(39), 6585 - 6595.

Yoon, Y., Gursoy, D. \& Chen, J. S. (2001). Validating a tourism development theory with structural equation modeling. Tourism Management, 22(4), 363-372. 